\title{
Is unilateral facial palsy truly caused by SARS-CoV-2?
}

\author{
A paralisia facial unilateral é realmente causada pelo SARS-CoV-2? \\ Josef FINSTERER', Fulvio Alexandre SCORZA², Carla A. SCORZA², Ana C. FIORIN/3,4
}

\section{Dear Editor,}

With interest, we read the article by Ribeiro et al. about a 26-year-old male with COVID-19 who developed right-sided facial palsy eight days after onset of the infection ${ }^{1}$. Facial palsy was interpreted as causally related to the viral infection ${ }^{1}$. We have the following comments and concerns.

The main shortcoming of the study is that a causal relation between facial palsy and COVID-19 was not substantiated. The cerebrospinal fluid (CSF) was neither tested for the presence of virus-RNA nor for inflammatory or immunological parameters. The pathogenesis of facial palsy was not sufficiently explained. An explanation should be provided as to why facial palsy occurred unilaterally. We should know whether neuritis of the intracranial portion of the facial nerve was assumed. In case facial palsy was related to COVID-19, we should know if neuritis had an infectious or immune-mediated cause.

A second shortcoming is that differentials of facial palsy were not sufficiently excluded. It should be noted if other viral infections, Borreliosis, sarcoidosis, otitis media, diabetes, nuclear ischemic stroke, trauma, malignancy, and Moebius syndrome were considered and sufficiently excluded.

A third shortcoming is that the treatment and outcome of facial palsy was not reported. One should know whether the patient survived pneumonia and, in case he survived, what happened to the facial palsy. Did the patient experience complete recovery or did the palsy persist despite recovery from pneumonia?

A fourth shortcoming is that there is no mentioning of the many previous reports about facial palsy in COVID-19 patients ${ }^{2,3,4}$. Differences and similarities between the current and previous cases should be discussed.

Overall, the case reported by Ribeiro et al. has not convincingly demonstrated that the infection with SARSCoV-2 was truly responsible for it or the neurological deficit. The pathophysiology of facial palsy should be explained, the treatment applied should be presented, and the outcome should be mentioned.

\section{References}

1. Ribeiro BNF, Marchiori E. Facial palsy as a neurological complication of SARS-CoV-2. Arq Neuro-Psiquiatr. 2020 0ct;78(10):667. https://doi. org/10.1590/0004-282X20200127

2. Khaja M, Gomez GP, Santana Y, Hernandez N, Haider A, Lara JL, et al. A 44-year-old Hispanic man with loss of taste and bilateral facial weakness diagnosed with Guillain-Barré syndrome and bell's palsy associated with SARS-CoV-2 infection treated with intravenous immunoglobulin. Am J Case Rep. 2020 Oct;21:e927956. https://doi.org/10.12659/AJCR.927956
Lima MA, Silva MT, Soares CN, Coutinho R, Oliveira HS, Afonso L, et al. Peripheral facial nerve palsy associated with COVID-19. J Neurovirol. 2020 Dec;26(6):941-4. https://doi.org/10.1007/s13365020-00912-6

4. Zammit M, Markey A, Webb C. A rise in facial nerve palsies during the coronavirus disease 2019 pandemic. J Laryngol Otol. 2020 Oct;1-4. https://doi.org/10.1017/ S0022215120002121

\footnotetext{
${ }^{1}$ Klinik Landstrasse, Messerli Institute, Vienna, Austria.

${ }^{2}$ Universidade Federal de São Paulo, Escola Paulista de Medicina, Disciplina de Neurociência, São Paulo SP, Brazil.

¿Universidade Federal de São Paulo, Escola Paulista de Medicina, Departamento de Fonoaudiologia, São Paulo SP, Brazil. (iD) https://orcid.org/0000-0001-7810-4748; Ana C. FIORINI (iD https://orcid.org/0000-0003-2989-2308

Correspondence: Josef Finsterer; E-mail: fifigs1@yahoo.de

Conflict of interest: There is no conflict of interest to declare.

Authors' contribution: JF: design, literature search, discussion, first draft, and critical comments.

Received on November 12, 2020; Accepted on November 13, 2020.
}

${ }^{3}$ Pontifícia Universidade Católica de São Paulo, Programa de Estudos Pós-Graduação em Fonoaudiologia, São Paulo SP, Brazil.

Josef FINSTERER (iD https://orcid.org/0000-0003-2839-7305; Fulvio Alexandre SCORZA (iD https://orcid.org/0000-0002-0694-8674; Carla A. SC0RZA 